\title{
Pemberdayaan Ekonomi Masyarakat Desa Tertinggal Melalui Pemanfaatan IPTEK
}

\author{
H.Abdul Malik, Arif Nugroho dan Ahmad Sururi \\ Fakultas Ilmu Sosial Dan Ilmu Politik \\ Universitas Serang Raya \\ Jalan Raya Cilegon Drangong Serang - Banten
}

\begin{abstract}
Abstraksi
Penelitian ini didesain untuk dapat memetakan potensi dan permasalahan sumber daya lokal dalam peningkatan ekonomi desa, pemahaman tentang kebutuhan teknologi untuk peningkatan perekonomian desa dan menyusun strategi pengembangan ekonomi desa melalui pendekatan teknologi untuk pengentasan kemiskinan. Metode yang digunakan dalam penelitian ini adalah analisis Location Quotient (LQ) untuk mengetahui ada tidaknya spesialisasi suatu wilayah untuk sektorsektor tertentu. Dengan analisis LQ dimaksudkan untuk melihat sektor yang menjadi sektor basis dan sektor bukan basis, kemudian dilanjutkan analisa kedalam analisis SWOT. Hasil penelitian menunjukan bahwa secara average indeks location quetion sebagian wilayah desa masing-masing mempunyai potensi ekonomi unggulan dan jika mengacu pada hasil perhitungan rata-rata Location Quetion (LQ) subsektor pertanian di atas maka terdapat sebagian besar desa yang mempunyai kriteria pencapaian ratarata perhitungan LQ nya lebih dari 1 (satu) atau LQ $>1$. Kemudian dalam penelitian ini juga telah dihasilkan rekomendasi secara operasional terhadap pemanfaatan IPTEK dari sektor unggulan yang telah dipetakan.
\end{abstract}

Kata Kunci : Pemberdayaan Ekonomi, Desa tertinggal, IPTEK

\begin{abstract}
This study was designed to map the potential and problems of local resources in improving the rural economy, an understanding of the technology needs for rural economic development and rural economic development strategy through technological approach to poverty alleviation. The method used in this study is a Location Quotient ( $L Q)$ to determine whether there is an area of specialization for certain sectors. By LQ analysis intended to look at sectors which are the basis of sectors and sectors not base, then continued into the analysis of SWOT analysis. Results showed that the average index of location quetion most rural areas each having economic potential seed and if it refers to the results of the calculation of average Location quetion $(L Q)$ subsector of agriculture at the top then there are many villages that have criteria for the achievement of the average calculation $L Q$ is greater than one (1) or LQ> 1. Later in this study have also been generated operationally recommendation against the use of science and technology of leading sectors that have been mapped.
\end{abstract}

Key Words : eywords: Economic Empowerment, Rural lagging, Science and Technology 


\section{PENDAHULUAN}

\section{a. Latar Belakang}

Otonomi daerah secara substantif memberikan keleluasaan (discretionary power) dari pemerintahan pusat kepada daerah untuk menyelenggarakan pemerintahan daerah dalam mewujudkan perubahan tata kehidupan pemerintahan daerah yang berimplikasi pada terciptanya masyarakat madani (civil society) dengan mengutamakan prinsip-prinsip good governance dengan berbasis kepada nilai-nilai demokrasi, keadilan, transparansi, kejujuran (honesty), orientasi pada kepentingan publik, dan tanggung jawab kepada masyarakat (responsibility to public).

Pemberdayaan masyarakat merupakan proses untuk memfasilitasi dan mendorong masyarakat agar mampu menempatkan diri secara proporsional dan menjadi pelaku utama dalam memanfaatkan lingkungan strategisnya untuk mencapai suatu keberlanjutan dalam jangka panjang. Pemberdayaan masyarakat memiliki keterkaitan erat dengan suistainable development dimana pemberdayaan masyarakat merupakan prasyarat utama serta dapat diibaratkan sebagai gerbong yang akan membawa masyarakat menuju suatu keberlanjutan ekonomi, sosial dan ekologi yang dinamis. (Mardikanto, 2014:92) ${ }^{1}$

Kemampuan masyarakat yang minim dalam mengakses sumber-sumber ekonomi menjadi penyebab terisolasinya masyarakat dan berdampak pada rendahnya kualitas hidup dan kesejahteraan masyarakat perdesaan secara umum. dengan demikian diperlukan perencanaan pembangunan dan formulasi dan strategi kebijakan pembangunan yang terintegrasi terutama menyangkut strategi pemberdayaan ekonomi masyarakat desa tertinggal melalui pemanfataan ilmu pengetahuan dan teknologi. Melalui perencanaan pembangunan dan formulasi kebijakan pembangunan yang terintegrasi diharapkan dapat mengidentifikasi permasalahan pembangunan yang dihadapi sehingga dapat dirumuskan program-program pembangunan berdasarkan analisis potensi ekonomi yang dimiliki.

Daerah tertinggal merupakan suatu kondisi dimana terdapat perbedaan tingkat perkembangan yang terjadi antara daerah satu dengan daerah lainya. Sejalan dengan diundangkannya Peraturan Pemerintah Nomor 78 Tahun 2014 Tentang Percepatan Pembangunan Daerah Tertinggal pada pasal 6 diatur tentang ketentuan penetapan daerah tertinggal, pemerintah mengidentifikasi ada 183 daerah tertinggal di Indonesia pada masa pembangunan lima tahun tahap dua (20102014). Daerah tertinggal ini semuanya terbesar di 34 kabupaten Daerah Otonom Baru. Pada periode pembangunan lima tahun sebelumnya yaitu pada tahun 2004-2009, ada 199 daerah tertinggal dan dengan program RPJMN 2004-2009 sebanyak 50 diantaranya telah keluar dari daftar daerah tertinggal. Unit terkecil daerah tertinggal yang digunakan dalam Strategi Nasional di Indonesia adalah wilayah administrasi Pemerintahan Kabupaten. Hal ini sesuai dengan kewenangan otonomi daerah yang secara penuh diberikan kepada pemerintah Kabupaten.

Penelitian ini dirancang untuk dapat memetakan potensi dan permasalahan sumber daya lokal dalam peningkatan ekonomi desa, pemahaman tentang kebutuhan teknologi untuk peningkatan perekonomian desa dan menyusun strategi pengembangan ekonomi desa melalui pendekatan teknologi untuk pengentasan kemiskinan, maka Pemerintahan Provinsi Banten melalui Badan Penelitian dan Pengembangan (BALITBANGDA) menyusun suatu kajian tentang pemberdayaan ekonomi masyarakat desa tertinggal melalui pemanfaatan IPTEK (Ilmu Pengetahuan dan Teknologi).

\section{b. Perumusan Masalah}

a) Adanya potensi ekonomi lokal yang terdapat di desa tertinggal

b) Masih terdapatnya permasalahan sumber daya lokal desa tertinggal 
c) Belum adanya strategi pengembangan ekonomi desa melalui pendekatan dan pemanfaatan teknologi

\section{c. Kajian Teori}

1) Pembangunan

Mengenai definisi dan istilah pembangunan itu sendiri, menurut Riyadi dalam Aprillia Theresia $^{2}$ (2014:2) mengemukakan bahwa "Pembangunan adalah suatu usaha atau proses perubahan demi tercapainya tingkat kesejahteraan atau mutu hidup suatu masyarakat (dan individuindividu di dalamnya) yang berkehendak dan melaksanakan program itu". Sedangkan menurut Todaro $^{3}$ (1997:25) mengemukakan "pembangunan juga merupakan proses multi dimensional yang menyangkut perubahanperubahan yang penting dalam suatu struktur, sistem sosial ekonomi, sikap masyarakat dan lembaga-lembaga nasional dan akselerasi pertumbuhan ekonomi, pengangguran kesenjangan dan pemberantasan kemiskinan absolut". Pengertian tersebut mengisyaratkan bahwa pembangunan berarti proses menuju perubahan-perubahan yang dimaksudkan untuk memperbaiki kualitas kehidupan masyarakat itu sendiri.

Dalam pengertian pembangunan para ahli memberikan berbagai macam definisi tentang pembangunan, namun secara umum ada suatu kesepakatan bahwa "pembangunan merupakan suatu proses yang berarti suatu kegiatan yang terus menerus dilaksanakan". Siagian $^{4}$ 1994:3 memberikan pengertian tentang pembangunan sebagai "suatu usaha atau rangkaian usaha pertumbuhan dan perubahan yang berencana dan dilakukan secara sadar oleh suatu bangsa, negara dan pemerintah, menuju modernitas dalam rangka pembinaan bangsa (Nation building)". Adapun Ginanjar Kartasasmita ${ }^{5}$ (1997:9) memberikan pengertian yang lebih sederhana tentang pembangunan yaitu: "suatu proses perubahan ke arah yang lebih baik melalui upaya yang dilakukan secara terencana".

\section{2) Partisipasi Masyarakat}

Dalam kamus sosiologi, partisipasi merupakan keikutsertaan seseorang didalam kelompok sosial untuk mengambil bagian dari kegiatan masyarakatnya, di luar pekerjaan atau profesinya sendiri (Mardikanto 2010).

Menurut Wibowo $^{6}(2011)$, partisipasi rakyat merupakan prasyarat utama untuk keberhasilan proses pembangunan di Indonesia. Namun hal ini belum menjadi perhatian utama karena di lapangan masih terdapat hambatan yaitu belum dipahaminya konsep partisipasi yang sebenarnya oleh pihak perencana dan pihak pembangunan. Kondisikondisi yang mendorong partisipasi menurut Ife dan Tesoriero $^{7}$ (2008) adalah sebagai berikut :

1) Mereka akan ikut berpartisipasi apabila mereka merasa bahwa isu atau aktivitas tersebut penting.

2) Orang harus merasa bahwa aksi mereka akan membuat perubahan.

3) Berbagai bentuk partisipasi harus diakui dan dihargai.

4) Orang harus bisa berpartisipasi dan didukung dalam partisipasinya.

5) Struktur dan proses tidak boleh mengucilkan.

\section{3) Pemberdayaan Ekonomi Masyarakat}

Menurut Ginanjar Kartasasmita, konsep pemberdayaan masyarakat mencakup pengertian "pembangunan masyarakat (community development) dan pembangunan yang bertumpu pada masyarakat (communitybased development). Pembangunan partisipatif mempunyai kaitan yang erat dengan pemberdayaan masyarakat, dimana pada pembangunan partisipatif diperlukan upaya dan langkah-langkah untuk mempersiapkan masyarakat guna memperkuat kelembagaan masyarakat agar mereka mampu mewujudkan kemajuan, kemandirian, dan kesejahteraan dalam suasana keadilan yang berkelanjutan untuk meningkatkan harkat dan martabatnya serta mampu melepaskan diri dari perangkap kemiskinan dan keterbelakangan. Upaya tersebut merupakan 
salah satu wujud nyata dari pemberdayaan masyarakat (Sumaryadi ${ }^{8}, 2005: 111$ ).

\section{4) Masyarakat Desa Tertinggal}

Ketertinggalan (underdevelopment) bukan merupakan sebuah kondisi dimana tidak terdapat perkembangan (absence of development), karena pada hakikatnya, setiap manusia atau kelompok manusia akan melakukan sebuah usaha untuk meningkatkan kualitas hidupnya walaupun itu hanya sedikit. Ketertinggalan merupakan sebuah kondisi suatu wilayah dengan wilayah lainya atau apabila kita membandingkan tingkat perkembangan suatu wilayah dengan wilayah lainya. daerah tertinggal secara umum memiliki karakteristik sebagai berikut (1)biasanya berada di kawasan pedesaan, (2)rendahnya sumberdaya yang dimiliki (SDM dan Sumberdaya Alam); (3) memiliki struktur pasar yang kecil dan tidak efektif; (4)rendahnya standar hidup; dan (5)sangat jauh dari wilayah pembangunan negara.

\section{5) Ilmu Pengetahuan Dan Teknologi (Iptek)}

Teknologi adalah satu ciri yang mendefinisikan hakikat manusia, yaitu bagian dari sejarahnya yang meliputi keseluruhan sejarah. Teknologi menurut berkaitan erat dengan sains (science) dan perekayasaan (engineering). Dengan kata lain, teknologi mengandung dua dimensi yaitu science dan engineering yang saling berkaitan satu sama lainnya. Sains mengacu pada pemahaman kita tentang dunia nyata sekitar kita, artinya mengenai ciri-ciri dasar pada dimensi ruang, tentang materi dan energi dalam interaksinya satu terhadap lainnya. IPTEK adalah akronim dari Ilmu Pengetahuan dan Teknologi, dimana dari akronim tersebut mempunyai artinya sendiri, baik Ilmu, Pengetahuan, maupun Teknologi. Ilmu dapatlah dipandang sebagai produk, sebagai proses, dan sebagai paradigma etika.Ilmu dipandang sebagai proses, karena ilmu merupakan hasil dari kegiatan sosial, yang berusaha memahami alam, manusia dan perilakuknya baik secara individu atau kelompok. Ilmu sebagai produk, artinya ilmu diperoleh dari hasil metode keilmuan yang diakui secara umum dan sifatnya yang universal. Oleh karena itu ilmu dapat diuji kebenarannya, sehingga tidak mustahil suatu teori yang sudah mapan suatu saat dapat ditumbangkan oleh teori lain. Ilmu sebagai paradigma ilmu, karena ilmu selain universal, komunal, juga alat meyakinkan sekaligus dapat skeptis, tidak begitu saja mudah menerima kebenaran.

\section{d. Tujuan}

1. Memetakan potensi dan permasalahan sumber daya lokal dalam peningkatan ekonomi desa.

2. Pemahaman tentang kebutuhan teknologi untuk peningkatan perekonomian desa

3. Menyusun strategi pengembangan ekonomi desa melalui pendekatan teknologi untuk pengentasan kemiskinan.

\section{BAHAN DAN METODE}

a) Lokasi dan Subjek Penelitian

Kegiatan kajian Pemberdayaan Ekonomi Masyarakat Desa Tertinggal Melalui Pemanfaatan IPTEK dilaksanakan di Provinsi Banten, yaitu di kabupaten Lebak dan Kabupaten Pandeglang dengan 4 (empat) lokus penelitian (Desa/Kelurahan) untuk masing - masing kabupaten yang merupakan kantong - kantong kemiskinan yang mewakili daerah pesisisr dan pegunungan yaitu :

1. Kabupaten Lebak, terdiri dari

- Kecamatan Malingping, Desa Pagelaran

- Kecamatan Wanasalam, Desa Sukatani

- Kecamatan Muncang, Desa Pasir eurih

- Kecamatan Curugbitung, Desa Candi

2. Kabupaten Pandeglang, terdiri dari

- Kecamatan Pagelaran, Desa Harapan Karya

- Kecamatan Mekar Jaya, Desa Kadujangkung

- Kecamatan Cadasari, Desa Kurung Dahu 
Kecamatan Mandalawangi, Desa Ramea

\section{b) Teknik Pengumpulan Data}

Teknik pengumpulan data yang dikumpulkan terdiri atas data primer dan data skunder. Data primer merupakan data yang langsung dikumpulkan pada saat melaksanakan penelitian di lapangan berupa wawancara, pengamatan langsung melalui komunikasi yang tidak secara langsung tentang pokok masalah. Sedangkan data sekunder adalah data yang merupakan hasil pengumpulan orang atau instansi dalam bentuk publikasi, laporan, dokumen, dan buku-buku lainnya yang berkaitan dengan penelitian ini. Pengumpulan data yang dilakukan dalam penelitian ini adalah melalui wawancara dan observasi. Wawancara dilakukan secara tidak tersruktur dan mendalam pada informan yang mempunyai kapasitas dan kompetensi terhadap permasalahan penelitian dengan menggunakan pedoman wawancara. Wawancara tidak terstruktur adalah jenis wawancara dimana dalam pelaksanaannya lebih bebas dibandingkan dengan wawancara terstruktur. Tujuan dari wawancara jenis ini adalah untuk menemukan permasalahan secara lebih terbuka, dimana pihak yang diajak wawancara diminta pendapat dan ideidenya. Observasi atau biasa dikenal dengan pengamatan adalah salah satu metode untuk melihat bagaimana suatu peristiwa, kejadian, hal-hal tertentu terjadi. Observasi menyajikan gambaran rinci tentang aktivitas program, proses dan peserta. Observasi dilakukan dengan melakukan pengamatan langsung untuk mencocokkan data dan informasi yang didapatkan dari hasil wawancara dengan keadaan sebenarnya di lapangan pada saat dimensi tertentu.

\section{c) Metode Analisis Data}

Metode analisis dalam penelitian ini dilakukan dengan menggunakan beberapa metode analisis yaitu:

\section{Analisis SWOT}

Model analisis SWOT yang digunakan dalam penelitian ini adalah yang diperkenalkan oleh Rangkuti ${ }^{9}$ tahun 1997. Analisis SWOT adalah identifikasi berbagai faktor secara sistematis didasarkan pada logika yang dapat memaksimalkan kekuatan (Strenghts) dan peluang (Opportunities), namun secara bersamaan dapat meminimalkan kelemahan (Weaknesses) dan ancaman (Threats) (Rusdarti, 2010). Analisis SWOT atau juga dikenal sebagai analisis situasi yaitu suatu analisis untuk mengidentifikasi berbagai faktor secara sistematis untuk merumuskan strategi atau kebijakan pada suatu sektor ekonomi. Analisis ini didasarkan pada logika yang dapat memaksimalkan kekuatan (strengths) dan peluang (opportunities), namun secara bersamaan dapat meminimalkan kelemahankelemahan (weakeness) dan ancaman (threats).

Dalam melakukan proses pengambilan keputusan strategis selalu berkaitan dengan pengembangan misi, tujuan, strategi dan kebijaksanaan. Dengan demikian perencanaan strategi (strategic planning) harus menganalisis faktor-faktor strategis yang dimiliki (kekuatan, kelemahan, peluang dan ancaman) dalam kondisi yang ada pada saat ini. Sehingga analisis SWOT juga dikenal dengan analisis situasi baik secara internal maupun eksternal.

\begin{tabular}{|c|c|c|}
\hline$Y^{-}$ & $\begin{array}{c}\text { Strenght (S) } \\
\text { Tentukan 5-10 faktor-faktor kekuatan } \\
\text { internal }\end{array}$ & $\begin{array}{c}\text { Weaknesses }(\mathbf{W}) \\
\text { Tentukan 5-10 faktor-faktor kelemahan } \\
\text { internal }\end{array}$ \\
\hline Opportunities (O) & Strategi (SO) & Strategi (WO) \\
\hline $\begin{array}{c}\text { Tentukan faktor peluang } \\
\text { Eksternal }\end{array}$ & $\begin{array}{c}\text { Ciptakan Strategi yang menggunakan } \\
\text { kekuatan untuk memanfaatkan }\end{array}$ & $\begin{array}{c}\text { Ciptakan strategi yang meminimalkan } \\
\text { kelemahan untuk memanfaatkan }\end{array}$ \\
\hline
\end{tabular}




\begin{tabular}{|c|c|c|}
\hline & peluang & peluang \\
\hline Threats (T) & Strategi (ST) & Strategi WT \\
$\begin{array}{c}\text { Tentukan faktor ancaman } \\
\text { eksternal }\end{array}$ & $\begin{array}{c}\text { Ciptakan strategi yang menggunakan } \\
\text { kekuatan untuk mengatasi ancaman }\end{array}$ & $\begin{array}{c}\text { Ciptakan strategi yang meminimalkan } \\
\text { kelemahan dan menghindari ancaman }\end{array}$ \\
\hline
\end{tabular}

\section{Analisis Location Quotient (LQ)}

Metode analisis Location Quotient (LQ) merupakan alat analisis untuk mengetahui ada tidaknya spesialisasi suatu wilayah untuk sektor (industri) tertentu. Dengan analisis LQ dimaksudkan untuk melihat sektor yang menjadi sektor basis dan sektor bukan basis, sehingga daerah melihat keunggulan sektor yangdapat dijual dan dikembangkan untuk mendorong perekonomian di daerah atau kabupaten. Sektor basis adalah kegiatan-kegiatan yang mengekspor barang dan jasa ke luar batas perekonomian wilayah yang bersangkutan. Sedangkan sektor non basis merupakan kegiatan-kegiatan yang menyediakan barang dan jasa untuk memenuhi kebutuhan orangorang yang bertempat tinggal didalam batasbatas perekonomian wilayah tersebut.
Disamping itu, teori ini juga dapat digunakan sebagai indikasi dampak pengganda (multiplier effect) bagi kegiatan perekonomian suatu wilayah. (Ambardi \& Socia, 2002).

Hasil perhitungan dengan klasifikasi sebagai berikut:

- Jika nilai LQ > 1, maka wilayah j untuk sektor i ada spesialisasi (tingkat spesialisasi wilayah >tingkat spesialisasi nasional)

- Jika nilai $L Q=1$, maka wilayah $\mathrm{j}>$ untuk sektor i ada spesialisasi (tingkat spesialisasi wilayah =tingkat spesialisasi nasional)

- Jika nilai LQ $<1$, maka wilayah j untuk sektor i tidak ada spesialisasi (tingkat spesialisasiwilayah < tingkat nasional).

\section{HASIL PENELITIAN DAN PEMBAHASAN}

\section{a) Hasil Analisis Location Quetion}

\section{REKAPITULASI INDEKS LOCATION QUETION} BERDASARKAN POTENSI EKONOMI/SUBSEKTOR UNGGULAN

\begin{tabular}{|c|c|c|c|c|}
\hline $\begin{array}{c}\text { Nama } \\
\text { Kabupaten }\end{array}$ & Nama Kecamatan & Nama Desa & $\begin{array}{c}\text { Potensi Ekonomi/ } \\
\text { Subsektor Unggulan }\end{array}$ & $\begin{array}{c}\text { Rata-rata } \\
\text { Location Quetion }\end{array}$ \\
\hline \multirow{4}{*}{$\begin{array}{l}\text { Kabupaten } \\
\text { Lebak }\end{array}$} & $\begin{array}{c}\text { Kecamatan Curug } \\
\text { Bitung }\end{array}$ & Desa Candi & $\begin{array}{ll}\text { 1. } & \text { Subsektor Padi dan Palawija } \\
\text { 2. } & \text { Subsektor sayuran } \\
\text { 3. } & \text { Subsektor Perkebunan } \\
\text { 4. } & \text { Subsektor Buah-buahan }\end{array}$ & $\begin{array}{l}0,861 \\
0,978 \\
0,790 \\
1,110\end{array}$ \\
\hline & Kecamatan Muncang & Desa Pasir Eurih & $\begin{array}{ll}\text { 1. } & \text { Subsektor Padi dan Palawija } \\
\text { 2. } & \text { Subsektor sayuran } \\
\text { 3. } & \text { Subsektor Perkebunan } \\
\text { 4. } & \text { Subsektor Buah-buahan } \\
\text { 5. } & \text { Subsektor Ternak \& Unggas }\end{array}$ & $\begin{array}{l}1,154 \\
0,908 \\
0,978 \\
1,382 \\
1,660\end{array}$ \\
\hline & $\begin{array}{l}\text { Kecamatan } \\
\text { Wanasalam }\end{array}$ & Desa Sukatani & $\begin{array}{ll}\text { 1. } & \text { Subsektor Padi dan Palawija } \\
\text { 2. } & \text { Subsektor sayuran } \\
\text { 3. } & \text { Subsektor Perkebunan } \\
\text { 4. } & \text { Subsektor Buah-buahan } \\
\text { 5. } & \text { Subsektor Ternak \& Unggas }\end{array}$ & $\begin{array}{c}1,463 \\
1,010 \\
1,00 \\
2,148 \\
1,606\end{array}$ \\
\hline & $\begin{array}{l}\text { Kecamatan } \\
\text { Malingping }\end{array}$ & Desa Pagelaran & $\begin{array}{ll}\text { 1. } & \text { Subsektor Padi dan Palawija } \\
\text { 2. } & \text { Subsektor sayuran } \\
\text { 3. } & \text { Subsektor Perkebunan }\end{array}$ & $\begin{array}{l}2,180 \\
1,006 \\
0,415\end{array}$ \\
\hline
\end{tabular}




\begin{tabular}{|c|c|c|c|c|}
\hline & & & $\begin{array}{ll}\text { 4. } & \text { Subsektor Buah-buahan } \\
\text { 5. } & \text { Subsektor Ternak \& Unggas } \\
\text { 6. } & \text { Subsektor Budidaya Ikan } \\
\end{array}$ & $\begin{array}{l}0,985 \\
0,893 \\
0,864 \\
\end{array}$ \\
\hline \multirow{4}{*}{$\begin{array}{l}\text { Kabupaten } \\
\text { Pandeglang }\end{array}$} & Kecamatan Cadasari & Desa Kurung Dahu & $\begin{array}{ll}\text { 1. } & \text { Subsektor Padi dan Palawija } \\
\text { 2. } & \text { Subsektor sayuran } \\
\text { 3. } & \text { Subsektor Perkebunan } \\
\text { 4. } & \text { Subsektor Buah-buahan } \\
\text { 5. } & \text { Subsektor Ternak \& Unggas }\end{array}$ & $\begin{array}{l}0,542 \\
0,928 \\
1,018 \\
0,920 \\
0,930\end{array}$ \\
\hline & $\begin{array}{c}\text { Kecamatan Mekar } \\
\text { Jaya }\end{array}$ & $\begin{array}{l}\text { Desa Kadu } \\
\text { Jangkung }\end{array}$ & $\begin{array}{ll}\text { 1. } & \text { Subsektor Padi dan Palawija } \\
\text { 2. } & \text { Subsektor sayuran } \\
\text { 3. } & \text { Subsektor Perkebunan } \\
\text { 4. } & \text { Subsektor Buah-buahan }\end{array}$ & $\begin{array}{l}1,052 \\
0,852 \\
0,994 \\
0,687\end{array}$ \\
\hline & $\begin{array}{c}\text { Kecamatan } \\
\text { Mandalawangi }\end{array}$ & Desa Ramea & $\begin{array}{ll}\text { 1. } & \text { Subsektor Padi dan Palawija } \\
\text { 2. } & \text { Subsektor sayuran } \\
\text { 3. } & \text { Subsektor Perkebunan } \\
\text { 4. } & \text { Subsektor Buah-buahan } \\
\end{array}$ & $\begin{array}{l}1,338 \\
0,779 \\
1,018 \\
0,907\end{array}$ \\
\hline & Kecamatan Pagelaran & $\begin{array}{c}\text { Desa Harapan } \\
\text { Karya }\end{array}$ & $\begin{array}{ll}\text { 1. } & \text { Subsektor Padi dan Palawija } \\
\text { 2. } & \text { Subsektor sayuran } \\
\text { 3. } & \text { Subsektor Perkebunan } \\
\text { 4. } & \text { Subsektor Ternak/Unggas }\end{array}$ & $\begin{array}{l}1,028 \\
0,962 \\
0,914 \\
0,895\end{array}$ \\
\hline
\end{tabular}

Sumber : Kecamatan dalam angka, data diolah

Data rekapitulasi di atas menunjukkan bahwa secara average indeks location quetion sebagian wilayah desa masing-masing mempunyai potensi ekonomi unggulan dan jika mengacu pada hasil perhitungan rata-rata Location Quetion (LQ) subsektor pertanian di atas maka terdapat sebagian besar desa yang mempunyai kriteria pencapaian rata-rata perhitungan LQ nya lebih dari 1 (satu) atau LQ > 1 dan berada pada sektor basis yaitu

1. Desa Candi Kecamatan Curug Bitung yang mempunyai potensi ekonomi unggulan pada subsektor buah-buahan.

2. Desa Pasir Eurih Kecamatan Muncang yang mempunyai potensi unggulan di subsektor padi dan palawija, perkebunan dan ternak/unggas.

3. Desa Sukatani Kecamatan Wanasalam yang mempunyai potensi unggulan di subsektor padi dan palawija, sayuran dan sektor buah-buahan.

4. Desa Pagelaran Kecamatan Malingping yang mempunyai potensi unggulan di subsektor padi dan palawija dan subsektor sayuran.

Selain komoditi padi dan palawija dan sayuran, Desa Pagelaran memiliki komoditas unggulan yang dapat dikembangkan yaitu home industri makanan opak yang dikenal dengan nama “opak pagelaran”.
5. Desa Kurung Dahu Kecamatan Cadasari yang mempunyai potensi unggulan pada subsektor perkebunan,

6. Desa Kadu Jangkung Kecamatan Mekar Jaya yang mempunyai potensi unggulan pada subsektor padi dan palawija.

Selain komoditas padi dan palawija, Desa Kadu Jangkung memiliki home industri kerajinan anyaman dari bahan pandan yang dikelola secara tradisional oleh sebagian besar kaum perempuan dan merupakan warisan turun temurun.

7. Desa Ramea Kecamatan Mandala Wangi yang mempunyai potensi unggulan di subsektor padi/palawija dan perkebunan.

Selain komoditas/subsektor padi dan palawija dan perkebunan, pengembangan subsektor ternak/unggas sudah dilaksanakan di Desa Ramea pada tahun 2015 dengan menerapkan sistem peternakan cluster atau peterrnakan yang ditempatkan di satu titik yaitu di Kampung Turalak sebagai sentra ternak.

8. Desa Harapan Karya Kecamatan Pagelaran yang mempunyai potensi ekonomi unggulan di sektor padi dan palawija.

Kriteria indeks LQ > 1 adalah kriteria yang menggambarkan identifikasi potensi ekonomi unggulan yang terdapat di suatu wilayah sekaligus menjelaskan bahwa sektorsektor tersebut merupakan sektor basis atau 
menjadi sumber pertumbuhan, keunggulan komparatif dan hasilnya tidak saja dapat memenuhi kebutuhan di wilayah bersangkutan akan tetapi juga dapat diekspor ke luar wilayah.

\section{b) Hasil Analisis SWOT}

Pemberdayaan ekonomi masyarakat desa tertinggal melalui pemanfaatan Iptek merupakan salah satu upaya dalam memanfaatkan peluang dan tantangan dalam mendorong dan menumbuhkan ekonomi masyarakat. Potensi yang dimiliki oleh Kabupaten Lebak dan Kabupaten Pandeglang cukup beragam akan tetapi masih terbatas dalam pengelolaannya dikarenakan masih terbatasnya aksebilitas masyarakat dalam memanfaatkan sumber daya ekonomi, minimnya infrastruktur pendukung, minimnya pengetahuan manajeman usaha, terbatasnya bimbingan dan pelatihan bagi masyarakat, pola orientasi masyarakat yang masih minim dalam pemenuhan kebutuhan sehari-hari dan minimnya pemanfaatan aspek ilmu pengetahuan dan teknologi.

Dan berikut ini akan diuraikan analisis masing-masing desa berdasarkan analisa SWOT.

\section{Desa Candi Kecamatan Curug Bitung}

Perumusan strategi pemberdayaan ekonomi masyarakat desa tertinggal dilakukan dengan menggunakan analisis SWOT dengan berdasarkan pada faktor-faktor lingkungan strategis, hasil generating dari matriks SWOT diuraikan pada tabel berikut ini :

TABEL 1

STRATEGI PEMBERDAYAAN EKONOMI MASYARAKAT DESA CANDI KECAMATAN CURUG BITUNG KABUPATEN LEBAK

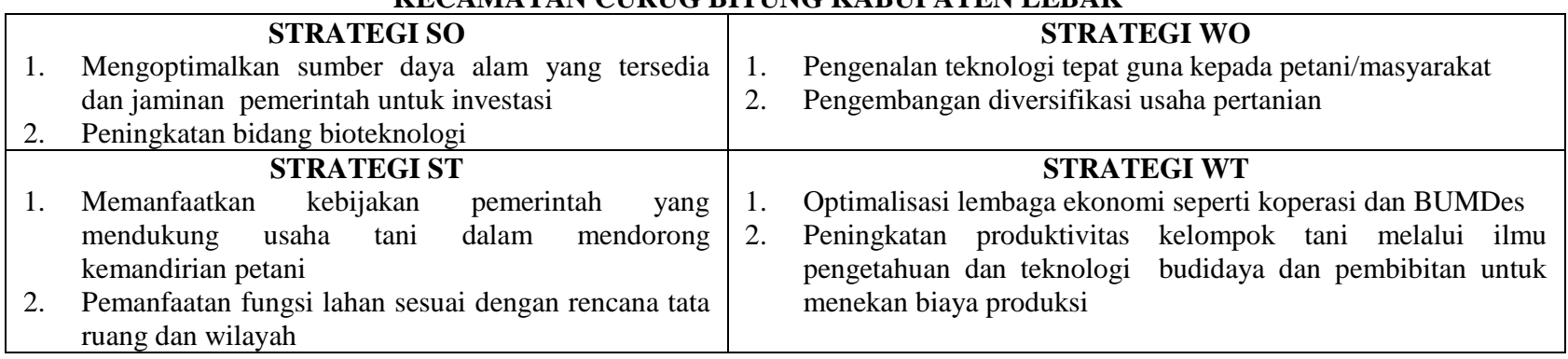

\section{Desa Pasir Eurih Kecamatan Muncang}

Perumusan strategi pemberdayaan ekonomi masyarakat desa tertinggal dilakukan dengan menggunakan analisis
SWOT dengan berdasarkan pada faktor-faktor lingkungan strategis, hasil generating dari matriks SWOT diuraikan pada tabel berikut ini :

TABEL 2 STRATEGI PEMBERDAYAAN EKONOMI MASYARAKAT DESA PASIR EURIH KECAMATAN MUNCANG KABUPATEN LEBAK

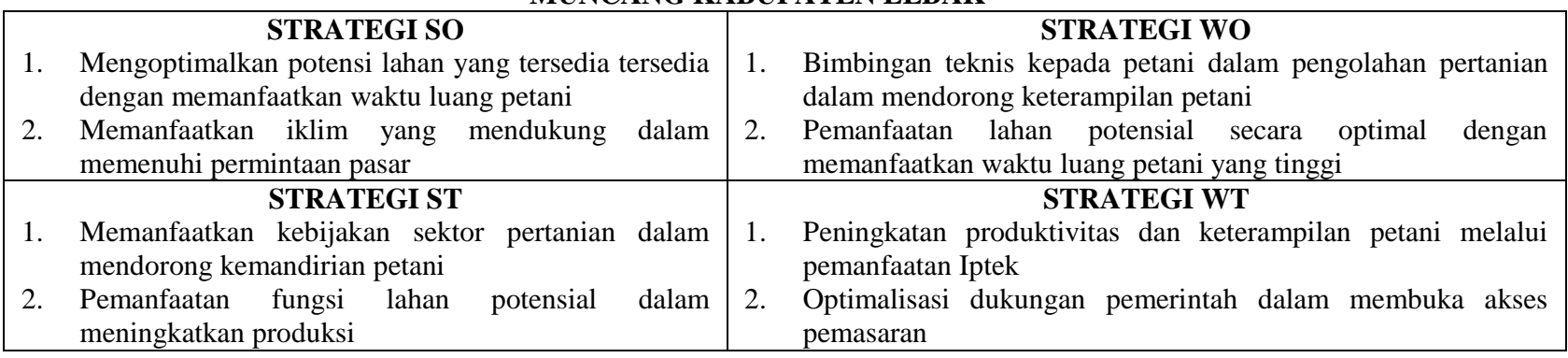




\section{Desa Sukatani Kecamatan Wanasalam}

Perumusan strategi pemberdayaan ekonomi masyarakat desa tertinggal dilakukan dengan menggunakan analisis
SWOT dengan berdasarkan pada faktor-faktor lingkungan strategis, hasil generating dari matriks SWOT diuraikan pada tabel berikut ini :

TABEL 3

STRATEGI PEMBERDAYAAN EKONOMI MASYARAKAT DESA SUKATANI KECAMATAN WASANALAM KABUPATEN LEBAK

\section{STRATEGI SO STRATEGI WO}

1. Mengoptimalkan semangat kerja yang tinggi dalam memenuhi permintaan pasar

2. Memanfaatkan potensi sumber daya alam untuk pengembangan sektor agro industri

\section{STRATEGI ST}

1. Mengoptimalkan penyuluhan kepada petani dalam mengantisipasi perdagangan bebas

2. Meningkatkan diversifikasi produk dan pengembangan agro industri

3. Peningkatan keberdayaan dan kemandirian petani melalui peningkatan SDM petani

4. Pemanfaatan fungsi lahan sesuai dengan rencana tata ruang wilayah

STRATEGI WT

1. Pemberian penyuluhan kepada petani dalam mengatasi serangan hama pertanian

2. Penyediaan infrastruktur

\section{Desa Pagelaran Kecamatan Malingping}

Perumusan strategi pemberdayaan ekonomi masyarakat desa tertinggal dilakukan dengan menggunakan analisis
SWOT dengan berdasarkan pada faktor-faktor lingkungan strategis, hasil generating dari matriks SWOT diuraikan pada tabel berikut ini :

TABEL 4

STRATEGI PEMBERDAYAAN EKONOMI MASYARAKAT DESA PAGELARAN KECAMATAN MALINGPING KABUPATEN LEBAK

STRATEGI SO STRATEGI WO

1. Mengoptimalkan iklim daerah tropis melalui 1. Menyediakan bantuan permodalan kepada petani dalam pengembangan bioteknologi tanaman memanfaatkan pengembangan pertanian

2. Memanfaatkan kebijakan pemerintah daerah yang mendukung dalam mengembangkan informasi dan teknologi

2. Memanfaatkan teknologi yang modern melalui informasi dan teknologi

\begin{tabular}{l|l} 
STRATEGI ST & STRATEGI WT
\end{tabular}

1. Memanfaatkan kebijakan daerah yang mendukung dalam mengatasi alih fungsi lahan

2. Memanfaatkan ketersediaan bahan baku dalam mengatasi serangan hama pertanian dan perkebunan

1. Pemberian penyuluhan kepada petani dalam mengatasi serangan hama pertanian

2. Penyediaan sarana dan prasarana dalam mendorong pertumbuhan ekonomi lokal.

\section{Desa Kurung Dahu Kecamatan Cadasari}

Perumusan strategi pemberdayaan ekonomi masyarakat desa tertinggal dilakukan dengan menggunakan analisis

SWOT dengan berdasarkan pada faktor-faktor lingkungan strategis, hasil generating dari matriks SWOT diuraikan pada tabel berikut ini :

TABEL 5

STRATEGI PEMBERDAYAAN EKONOMI MASYARAKAT DESA KURUNG DAHU KECAMATAN CADASARI KABUPATEN PANDEGLANG

\section{STRATEGI SO}

1. Mengoptimalkan sumber daya alam ekonomi yang tersedia dalam memanfaatkan kemajuan bidang bioteknologi tanaman

2. Memanfaatkan kebijakan pemerintah daerah dalam memenuhi permintaan pasar.

\section{STRATEGI WO}

1. Mendirikan lembaga BUMDes/ koperasi untuk mendorong kemandirian petani

2. Pengenalan teknologi tepat guna kepada petani/masyarakat untuk mengantisipasi serangan hama 


\begin{tabular}{|c|c|c|}
\hline \multicolumn{2}{|r|}{ STRATEGI ST } & STRATEGI WT \\
\hline 1. & $\begin{array}{l}\text { Memanfaatkan kebijakan pemerintah yang } \\
\text { mendukung usaha tani dalam mendorong kemandirian }\end{array}$ & $\begin{array}{l}\text { 1. Pemanfaatan lahan secara optimal dalam mengantisipas alih } \\
\text { fungsi lahan }\end{array}$ \\
\hline 2. & $\begin{array}{l}\text { petani } \\
\text { Pemanfaatan fungsi lahan sesuai dengan rencana tata } \\
\text { ruang dan wilayah }\end{array}$ & $\begin{array}{l}\text { Peningkatan produktivitas kelompok tani melalui ilmu } \\
\text { pengetahuan dan teknologi budidaya dan pembibitan untuk } \\
\text { menekan biaya produksi }\end{array}$ \\
\hline
\end{tabular}

\section{Desa Kadu Jangkung Kecamatan Mekar Jaya \\ Perumusan strategi pemberdayaan ekonomi masyarakat desa tertinggal dilakukan dengan menggunakan analisis}

SWOT dengan berdasarkan pada faktor-faktor lingkungan strategis, hasil generating dari matriks SWOT diuraikan pada tabel berikut ini :

TABEL 6

STRATEGI PEMBERDAYAAN EKONOMI MASYARAKAT DESA KADU JANGKUNG KECAMATAN MEKAR JAYA

\begin{tabular}{|c|c|}
\hline EGI SO & \\
\hline $\begin{array}{l}\text { 1. Mengoptimalkan potensi lahan yang tersedia dengan } \\
\text { memanfaatkan bantuan bibit dan pupuk } \\
\text { 2. Memanfaatkan kebijakan pertanian untuk memenuhi } \\
\text { permintaan pasar }\end{array}$ & $\begin{array}{l}\text { 1. Memanfaatkan jaringan pemasaran melalui pengembangan } \\
\text { koperasi } \\
\text { 2. Bimbingan teknis kepada petani dalam pengolahan pertanian } \\
\text { dalam mendorong keterampilan petani }\end{array}$ \\
\hline EGI ST & \\
\hline $\begin{array}{l}\text { 1. Memanfaatkan kebijakan sektor pertanian dalam } \\
\text { mendorong kemandirian petani } \\
\text { 2. Pemanfaatan fungsi lahan potensial dalam } \\
\text { meningkatkan produksi }\end{array}$ & $\begin{array}{l}\text { 1. Bimbingan teknis dan penyuluhan kepada petani untuk } \\
\text { mengurangi dan mengantisipasi serangan hama } \\
\text { 2. Optimalisasi dukungan pemerintah dalam membuka akses } \\
\text { pemasaran }\end{array}$ \\
\hline
\end{tabular}

\section{Desa Ramea Kecamatan} Mandalawangi

Perumusan strategi pemberdayaan ekonomi masyarakat desa tertinggal dilakukan dengan menggunakan analisis
SWOT dengan berdasarkan pada faktor-faktor lingkungan strategis, hasil generating dari matriks SWOT diuraikan pada tabel berikut ini :

TABEL 7

STRATEGI PEMBERDAYAAN EKONOMI MASYARAKAT RAMEA

KECAMATAN MANDALAWANGI KABUPATEN PANDEGLANG

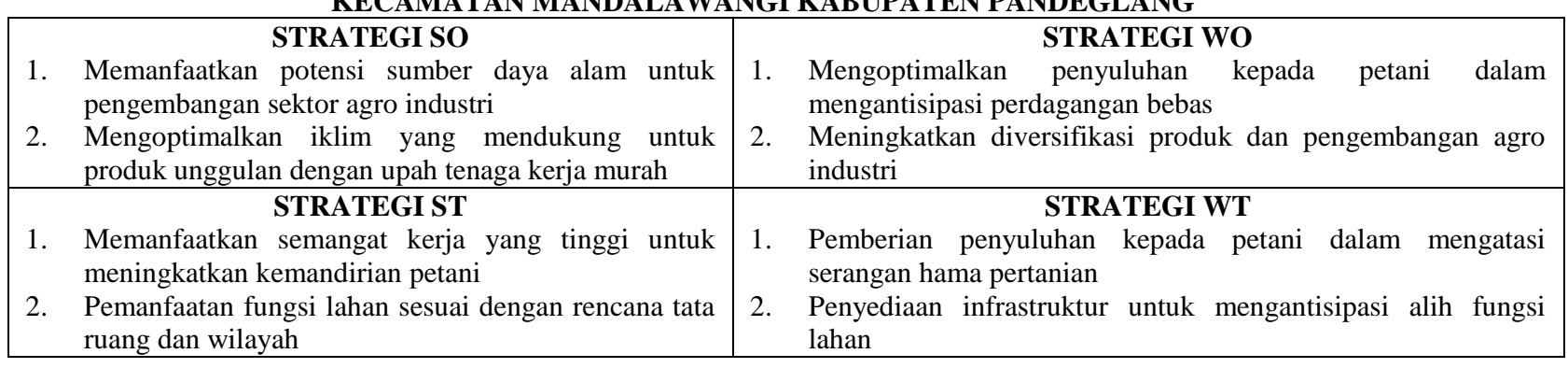

\section{Desa Harapan Karya Kecamatan Pagelaran}

Perumusan strategi pemberdayaan ekonomi masyarakat desa tertinggal dilakukan dengan menggunakan analisis
SWOT dengan berdasarkan pada faktorfaktor lingkungan strategis, hasil generating dari matriks SWOT diuraikan pada tabel berikut ini 
TABEL 8

STRATEGI PEMBERDAYAAN EKONOMI MASYARAKAT

DESA HARAPAN KARYA KECAMATAN PAGELARAN

KABUPATEN PANDEGLANG

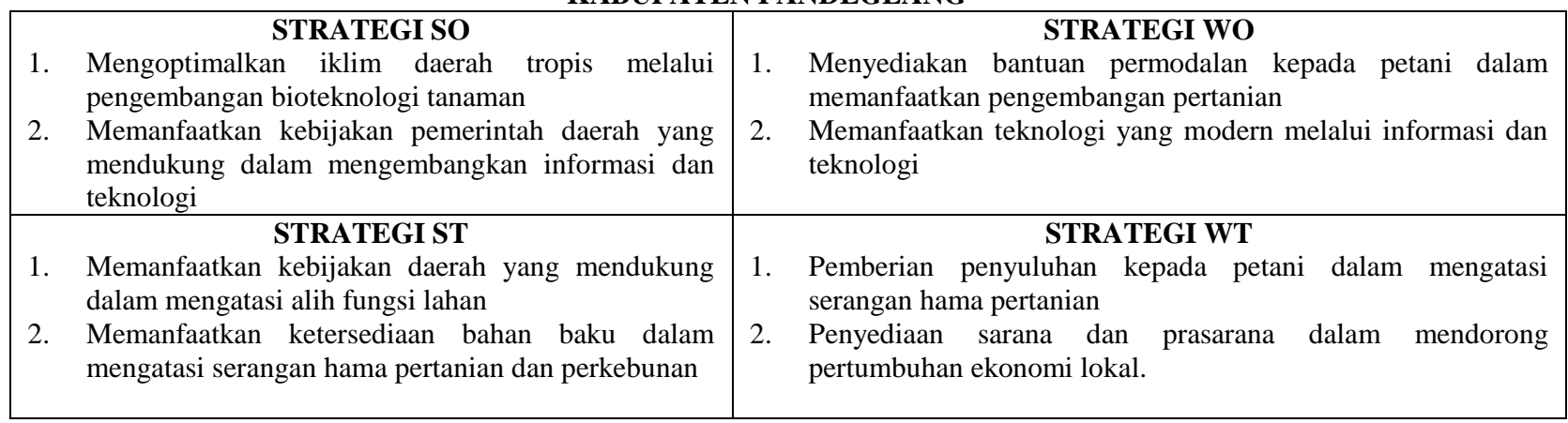

\section{KESIMPULAN DAN SARAN}

Setelah melakukan serangkaian analisis dengan berbagai pendekatan, dapat ditarik kesimpulan dari penelitian ini berdasarkan potensi ekonomi lokal, permasalahan sumber daya lokal dan strategi pengembangan ekonomi desa melalui pendekatan dan pemanfaatan teknologi yaitu sebagai berikut :

\section{a. Desa Candi Kecamatan Curug Bitung}

1) Potensi Ekonomi Lokal

Potensi ekonomi lokal yang dimiliki adalah sektor pertanian dimana hampir sebagian besar kepala keluarga di Desa Candi bermata pencaharian sebagai petani dengan didukung oleh 7 (tujuh) kelompok tani, keunggulan sumber daya manusia yang dimiliki terutama usia produktif dan perkebunan serta sektor ladang. Potensi ekonomi unggulan adalah sektor buah-buahan manggis, yang artinya sektor buah-buahan merupakan sektor basis yaitu sektor yang mempunyai nilai potensi ekonomi tinggi, dapat memenuhi kebutuhan masyarakat secara mandiri dan dapat diekspor ke luar wilayah desa.

2) Permasalahan Sumber Daya Lokal

Sedangkan permasalahan sumber daya lokal Desa Candi Kecamatan Curug Bitung adalah masih tradisionalnya pengelolaan pertanian dan perkebunan, masih terbatasnya pasokan sumber air irigasi untuk lahan pertanian dan masih terbatasnya akses pemasaran hasil-hasil pertanian dan perkebunan disebabkan karena akses jalan rusak dan jarak tempuh yang cukup jauh.

3) Strategi pengembangan ekonomi desa melalui pendekatan dan pemanfaatan teknologi

Kebutuhan dan pemanfaatan teknologi yang diperlukan seuai dengan potensi unggulan buah-buahan adalah pengolahan minuman sari buah manggis segar dan kulit manggis (mesin ekstra buah dengan dimensi 34 x 27 x $36 \mathrm{~cm}$, kapasitas 80-100 $\mathrm{kg} / \mathrm{jam}$, daya $370 \mathrm{Watt}$, berat $12 \mathrm{~kg}$, kecepatan $200 \mathrm{rpm}$ ), alat pengolahan kulit buah manggis kering dan tepung kulit buah manggis (oven Pengering spesifikasi dimensi tergantung, tipe material rangka siku, sthal besi material, body luar plat besi atau stainless steel, material body dalam plat besi atau stainless steel, material rak screen atau plat besi atau stainless steel, pemanas LPG, sistem pemanasan sirkulasi tanduk rusa, thermokontrol otomatis blower) \& alat pengolahan sirup manggis (spesifikasi dimensi : 1000 x $1000 \mathrm{x}$ $1300 \mathrm{~mm}$, rangka : besi kanal/UNP tabung : stenliss foodgrade, pemanas 
: LPG kapasitas : 200 liter), pengemas produk, selain alat-alat tersebut diperlukan pula tutorial singkat \& modul tentang cara pengolah dan penggunaan alat.

\section{b. Desa Pasir Eurih Kecamatan Muncang}

1) Potensi Ekonomi Lokal

Potensi ekonomi lokal yang dimiliki adalah sumber daya alam, hasil pertanian, populasi peternakan dan hasil perkebunan ladang. Hasil pertanian Desa Pasir Eurih adalah padi dan palawija sedangkan hasil perkebunan buah-buahan yang dihasilkan adalah rambutan dan nangka, selain itu sektor ternak dan unggas di Desa Pasir Eurih dapat menjadi alternatif unggulan yaitu kambing/domba dan itik/bebek.

2) Permasalahan Sumber Daya Lokal

Permasalahan sumber daya lokal di Desa Pasir Eurih adalah masih tradisionilnya pengelolaan sektorsektor pertanian dan perkebunan, terbatasnya akses pemasaran hasil pertanian dan perkebunan serta belum adanya pemanfaatan Iptek.

3) Strategi pengembangan ekonomi desa melalui pendekatan dan pemanfaatan teknologi

Strategi pengembangan ekonomi yang dapat dilakukan adalah kebijakan mekanisasi perkebunan melalui dukungan kebijakan pemerintah dalam menyediakan kebutuhan teknologi dan akses pemasaran. Desa Pasir Eurih Kecamatan Muncang memiliki potensi unggulan di beberapa subsektor seperti padi dan palawija, buah-buahan, ternak/unggas dan perkebunan (kopi, kelapa, cengkeh dan aren), dimana perlu dilakukannya suatu inovasi guna peningkatan faedah dan nilai ekonominya sbb.

a) Untuk sub sektor unggulan kopi, diperlukan alat-alat produksi skala kecil/ industri rumah tangga seperti mesin pengupas kulit basah, mini dryer stainless stell, Mesin Penggongseng, Mesin 36 Grain Moisture Meter, Penyangrai (China), \& alat pengemas serta diberikan tutorial serta modul terkait teknologi produksi, pemanfaatan produk \& startegi pemasaran.

b) Untuk sub sektor unggulan kelapa, diperlukan alat-alat produksi skala kecil/industri rumah tangga seperti alat pembuatan tepung kelapa (pengeringan/artificial drying), alat pembuatan karbon aktif, alat pembuatan gula kelapa, serta tutorial dan modul terkait teknologi produksi, pemanfaatan produk, startegi pemasaran.

c) Untuk sub sektor unggulan cengkeh, memberikan alat-alat produksi skala kecil/ industri rumah tangga seperti alat untuk memproduksi minyak atsiri/minyak cengkeh, yaitu home essential oil distiller, alat pemisah minyak asiri/atsiri (oil separator), alat keselamatan/sabuk pengaman untuk pemanenan cengkeh, serta tutorial dan modul pengoperasian, inovasi, pemanfaatan produk.

d) Untuk sub sektor unggulan aren dengan alat pegolahan gula aren seperti (1 mesin katalisator gula semut dengan spesifikasi Pengaduk kayu model garpu, kontak produk stenliss, kerangka besi siku, Penggerak Eletro Motor 3/4 atau $1 \mathrm{Hp} \mathrm{220V/motor} \mathrm{Bensin}$ 5,5 HP, Dimensi 800x600x800mm 2 Oven pengering gula semut dengan spesifikasi kontak produk stenliss, Platezzer, Kerangka besi siku, pemanas gas, Dimensi $800 \times 600 \times 800 \mathrm{~mm}$ ) serta tutorial dan modul pengoperasian, 
pemanfaatan produk \& startegi pemasaran.

\section{c. Desa Sukatani Kecamatan Wanasalam}

1) Potensi Ekonomi Lokal

Potensi ekonomi lokal yang dimiliki adalah sumber daya alam, hasil pertanian (padi dan palawija), peternakan dan perkebunan buahbuahan. Ketiga sektor tersebut dapat menjadi sumber pertumbuhan dan penggerak perekonomian desa.

2) Permasalahan Sumber Daya Lokal Permasalahan sumber daya lokal adalah masih tradisionilnya pengelolaan sektor-sektor pertanian dan perkebunan, terbatasnya akses pemasaran hasil pertanian, peternakan dan perkebunan.

3) Strategi pengembangan ekonomi desa melalui pendekatan dan pemanfaatan teknologi

Desa Sukatani Kecamatan Wanasalam memiliki potensi unggulan di beberapa subsektor pertanian padi dan palawija, buah-buahan, ternak dan unggas dimana perlu dilakukannya suatu inovasi dalam peningkatan faedah dan nilai ekonomi yaitu dengan bantuan bibit unggul, tutorial terkait peningkatan kuantitas panen serta alat-alat pertanian moderen seperti traktor (menggunakan mesin penggerak dengan tenaga $6.5 \mathrm{HP}$, bodi terbuat dari besi cor, dilengkapi dengan kopling belok), mesin pengairan sawah (Pompa Pertanian/Irigasi CC40WP-LPG ), pupuk, pembasmi hama.

\section{d. Desa Pagelaran Kecamatan Malingping}

1) Potensi Ekonomi Lokal

Potensi ekonomi lokal yang dimiliki adalah sumber daya alam, hasil pertanian (jagung dan kacang tanah). Selain itu Desa Pagelaran memiliki sumber daya lokal unggulan yaitu home industri dengan produksi makanan opak atau dikenal dengan sebutan "opak pagelaran" yang dikelola secara tradisional oleh masyarakat setempat, komoditi tersebut dapat menjadi sumber pertumbuhan dan penggerak perekonomian desa.

2) Permasalahan Sumber Daya Lokal Permasalahan sumber daya lokal adalah masih tradisionilnya pengelolaan sektor-sektor pertanian dan terbatasnya akses pemasaran sumber daya ekonomi lokal.

3) Strategi pengembangan ekonomi desa melalui pendekatan dan pemanfaatan teknologi

Desa Pagelaran memiliki potensi unggulan di sektor pertanian padi dan palawija (Jagung \& kacang tanah), industri makanan opak, dan perlu adanya suatu inovasi guna peningkatan faedah dan nilai ekonomi yaitu dengan bantuan bibit unggul padi, jagung \& kacang tanah, tutorial terkait peningkatan kuantitas panen serta alatalat pertanian moderen seperti traktor (menggunakan mesin penggerak dengan tenaga $6.5 \mathrm{HP}$, bodi terbuat dari besi cor , dilengkapi dengan kopling belok), mesin pengairan sawah (Pompa Pertanian/Irigasi CC40WPLPG ), pupuk, pembasmi hama.

Untuk industri makanan cemilan opak diperlukan tutorial terkait inovasi produk opak, alat pengolahan opak secara moderen dan higienis, kemasan, serta modul, tutorial penggunaan alat.

Khusus untuk sentra produksi makanan opak yang dikelola secara tradisional oleh masyarakat diperlukan adanya studi banding ke daerah lain yang telah berhasil pengelolaan sentra produksi makanan opak seperti kecamatan Kajoran Kabupaten Magelang.

\section{e. Desa Kurungdahu Kecamatan Cadasari}

1) Potensi Ekonomi lokal 
Potensi ekonomi di Desa Kurung

Dahu Kecamatan Cadasari adalah perkebunan cengkeh, hampir sebagian besar masyarakat desa mempunyai tanaman cengkeh dan menjadikan cengkeh sebagai komoditi unggulan masyarakat.

2) Permasalahan Sumber Daya Lokal.

Permasalahan sumber daya lokal adalah masih tradisionilnya pengelolaan komoditi cengkeh dan sektor-sektor lainnya seperti pertanian serta terbatasnya akses pemasaran sumber daya ekonomi lokal.

3) Strategi pengembangan ekonomi desa melalui pendekatan dan pemanfaatan teknologi.

Strategi pengembangan ekonomi yang dapat dilakukan adalah kebijakan inovasi dalam meningkatkan faedah dan nilai ekonominya yaitu dengan memberikan alat - alat produksi skala kecil/industri rumah tangga seperti alat untuk memproduksi minyak atsiri/minyak cengkeh, yaitu home essential oil distiller, alat pemisah minyak asiri/atsiri (oil separator), alat keselamatan/sabuk pengaman untuk pemanenan cengkeh, serta tutorial dan modul pengoperasian, inovasi, pemanfaatan produk.

\section{f. Desa Kadujangkung Kecamatan \\ Mekar Jaya}

1) Potensi Ekonomi lokal

Potensi ekonomi lokal di Desa Kadu Jangkung adalah industri kerajinan anyaman tas, tikar dan sapu dari bahan pandan selain sektor pertanian padi palawija dan komoditi kelapa sebagai komoditi unggulan.

2) Permasalahan Sumber Daya Lokal Permasalahan sumber daya lokal adalah masih tradisionilnya pengelolaan industri kerajinan anyaman, terbatasnya akses pemasaran dan pasokan sumber air untuk lahan pertanian karena masih memanfaatkan sumber air hujan.

3) Strategi pengembangan ekonomi desa melalui pendekatan dan pemanfaatan teknologi

Strategi pengembangan ekonomi yang dapat dilakukan adalah perlu adanya suatu inovasi guna peningkatan faedah dan nilai ekonominya. Untuk sektor unggulan kelapa, diperlukan alat-alat produksi skala kecil/industri rumah tangga seperti alat pembuatan tepung kelapa (pengeringan/artificial drying), alat pembuatan karbon aktif, alat pembuatan gula kelapa ( mesin katalisator gula semut, oven pengering gula semut), serta tutorial dan modul terkait teknologi produksi \& pemanfaatan produk.

Untuk sektor pertanian padi dan palawija yaitu dengan bantuan bibit unggul padi, tutorial terkait peningkatan kuantitas panen serta alat-alat pertanian moderen seperti traktor (menggunakan mesin penggerak dengan tenaga $6.5 \mathrm{HP}$, bodi terbuat dari besi cor, dilengkapi dengan kopling belok), mesin pengairan sawah ( Pompa Pertanian/Irigasi CC40WP-LPG ), pupuk, pembasmi hama. Untuk kerajinan anyaman bahan pandan, diperlukan tutorial kepada kelompok home industri kaum perempuan tentang inovasi produk kerajinan anyaman dari bahan dasar serat pandan, media promosi terkait perluasan akses pemasaran, pelatiahan terkait manajemen pelembagaan pengelolaan hasil produksi kerajinan anyaman pandan (penguatan manajemen perkoperasian) dan studi banding ke daerah lain yang telah berhasi dalam pengelolaan sentra kerajinan anyaman seperti sentra kerajinan anyaman Raponglah di Tasikmalaya 


\section{g. Desa Ramea Kecamatan Mandalawangi}

1) Potensi Ekonomi Lokal

Potensi ekonomi lokal Desa Ramea adalah sektor pertanian padi palawija, cengkeh dan melinjo. Selain itu di Desa Rame dikembangkan sentra produksi peternakan dengan sistem cluster yang terletak di Kampung Turalak dan sentra produksi gula aren.

2) Permasalahan Sumber Daya Lokal Permasalahan sumber daya lokal adalah pengelolaan hasil pertanian dan perkebunan yang masih tradisional, akses pemasaran yang terbatas disebabkan akses jalan yang rusak dan jarak tempuh yang cukup jauh.

3) Strategi pengembangan ekonomi desa melalui pendekatan dan pemanfaatan teknologi

Strategi pengembangan ekonomi desa yang dapat dilakukan adalah kebijakan inovasi guna peningkatan faedah dan nilai ekonominya. Untuk komoditi melinjo yaitu dengan memberikan alat-alat produksi skala kecil/ industri rumah tangga seperti alat untuk pengupas kulit melinjo basah, mini dryer stainless stell, mesin penggongseng, mesin pengupas melinjo kering, 36 grain moisture meter, penyangrai (china), serta alat penggepeng dalam pembuatan emping melinjo, krupuk melinjo, plastik kemasan, serta tutorial, modul pengoperasian, inovasi rasa produk melinjo \& Strategi pemasaran. Untuk komoditi unggulan cengkeh, diperlukan alat-alat produksi skala kecil/industri rumah tangga seperti alat untuk memproduksi minyak atsiri/minyak cengkeh, yaitu mesin destilasi, alat keselamatan/sabuk pengaman untuk pemanenan cengkeh, serta tutorial dan modul pengoperasian, pemanfaatan produk \& startegi Pemasaran. Untuk sektor padi dengan bibit unggul padi, tutorial terkait peningkatan kuantitas panen serta alat-alat pertanian modern seperti traktor, mesin pengairan sawah, pupuk, pembasmi hama \& modul, tutorial terkait pengelolaan pertanian padi. Untuk peternakan domba yaitu dengan memberikan bantuan alat cukur bulu domba manual, alat suntik otomatis metal, alat cekok otomatis, alat tes amonika kandang serta tutorial dan modul pengoperasian, pemanfaatan produk \& startegi Pemasaran. Untuk sektor gula aren dengan alat pegolahan gula aren seperti ( 1 mesin katalisator gula semut dengan spesifikasi Pengaduk kayu model garpu, kontak produk stenliss, Kerangka besi siku, Penggerak Eletro Motor 3/4 atau 1 Hp 220V / Motor Bensin 5,5 HP, Dimensi 800x600x800mm. 2.Oven pengering gula semut dengan spesifikasi kontak produk stenliss, Platezzer, Kerangka besi siku, pemanas gas, Dimensi $800 \times 600 \times 800 \mathrm{~mm}$ ) serta tutorial dan modul pengoperasian, pemanfaatan produk \& startegi Pemasaran

\section{h. Desa Harapan Karya Kecamatan Pagelaran}

1) Potensi Ekonomi Lokal

Potensi ekonomi lokal Desa Harapan Karya adalah padi dan palawija (padi sawah, ubi kayu dan kacang tanah) sebagai komoditi unggulan desa.

2) Permasalahan Sumber Daya Lokal Permasalahan sumber daya lokal adalah pengelolaan hasil pertanian padi dan palawija yang masih tradisional, akses pemasaran yang terbatas disebabkan akses jalan yang rusak dan jarak tempuh yang cukup jauh.

3) Strategi pengembangan ekonomi desa melalui pendekatan dan pemanfaatan teknologi 
Strategi pengembangan ekonomi Desa Harapan Karya yang memiliki potensi unggulan di sektor pertanian padi dan palawija (ubi kayu \& kacang tanah) adalah strategi dan kebijakan inovasi guna peningkatan faedah dan nilai ekonominya, yaitu dengan memberikan alat-alat produksi skala kecil/industri rumah tangga seperti alat-alat pembuatan tepung ubi kayu (mesin penggilingan \& mesin pemanas/oven), alat pengolahan produk kacang tanah (oven, alat pengupas kulit). Untuk sektor padi dengan bibit unggul padi, tutorial terkait peningkatan kuantitas panen serta alat-alat pertanian modern seperti traktor (menggunakan mesin penggerak dengan tenaga $6.5 \mathrm{HP}$, bodi terbuat dari besi cor, dilengkapi dengan kopling belok), mesin pengairan sawah (Pompa Pertanian/Irigasi CC40WP-LPG ), pupuk, pembasmi hama \& modul, tutorial terkait pengelolaan pertanian padi, pemanfaatan produk, penggunaan alat dan strategi pemasaran.

\section{REKOMENDASI}

Berdasarkan hasil kajian yang telah diuraikan sebelumnya, maka kami merekomendasikan sebagai berikut :

1. Keputusan strategis yang dapat segera dilaksanakan sesuai dengan analisis Location Quetion dan metode analisis SWOT adalah strategi dan rekomendasi kebijakan program pengembangan yang dapat diinisiasi oleh Pemerintah Daerah Provinsi Banten dan dinas-dinas terkait, pemerintah kabupaten, pemerintah kecamatan dan pemerintah desa dalam hal peningkatan dan pemberdayaan ekonomi masyarakat adalah penyediaan kebutuhan Iptek dalam mewujudkan ketahanan ekonomi, ketahanan pangan masyarakat dan kesejahteraan masyarakat.
2. Kebijakan dan rekomendasi strategis sebagai aspek pendukung dalam pemberdayaan ekonomi masyarakat desa adalah pembangunan infrastruktur jalan lingkungan dan poros desa di setiap desa dan kecamatan yang menjadi locus kajian untuk mendorong produktivitas dan akses pemasaran transportasi dari lokasi produksi ke pasar atau luar wilayah desa/kecamatan.

3. Pemerintah Provinsi Banten bersama stakeholder lainnya berupaya mengintegrasikan konsep pemberdayaan ekonomi masyarakat desa dan programprogram pembangunan sebagai bagian dari strategi pembangunan pemerintahan provinsi Banten dalam jangka pendek, jangka menengah maupun jangka panjang. 


\section{DAFTAR PUSTAKA}

1 Mardikanto T dan Soebiato P, 2013, Pemberdayaan Masyarakat. Bandung, Alfabeta

2 Theresia, Aprillia, at al, 214, Pembangunan Berbasis Masyarakat Bandung, Alfabeta

3 Michael, Todaro, 1977, Pembangunan ekonomi di dunia Ketiga, Jakarta Erlangga

4 Siagian, Sondang P, 1994, Administrasi Pembangunan, Jakarta, Gunung Agung

5 Ginanjar Kartasasmita, Ginanjar, 1997, Administrasi Pembangunan. Jakarta, LP3ES

6 Wibowo R. 2011. Pendekatan partisipatif masyarakat terhadap implementasi
Program Nasional Pemberdayaan Masyarakat (PNPM) Mandiri.

7 Ife J, Tesoriero F. 2008. Alternatif pengembangan masyarakat di era globalisasi community development. Yogyakarta [ID]:Pustaka Pelajar

8 Sumaryadi, I Nyoman, 2005, Perencanaan Pembangunan Daerah Otonom dan Pemberdayaan Masyarakat, Jakarta: Penerbit Citra Utama

9 Rangkuti, F. 2005. Analisis SWOT Teknik Membedah Kasus Bisnis: Reoriantasi Konsep Perencanaan Strategis Untuk Menghadapi Abad 21. Cetakan Keduabelas. Jakarta: PT Gramedia Pustaka Utama 